IJMS 17 (1), 189-202 (2010)

\title{
ANALISIS KECEKAPAN RELATIF BAGI INDUSTRI SAHAM AMANAH MENGGUNAKAN PENDEKATAN EKONOMETRIK
}

\author{
NOR AZLIDA ALENG @ MOHAMAD \\ WAN MUHAMAD AMIR WAN AHMAD \\ MUSTAFA MAMAT \\ Fakulti Sains dan Teknologi \\ Universiti Malaysia Terengganu \\ ZAIDI ISA \\ Fakulti Sains dan Teknologi \\ Universiti Kebangsaan Malaysia
}

\begin{abstract}
ABSTRAK
Makalah ini bertujuan untuk mengukur kecekapan relatif industri saham amanah di Malaysia menggunakan kaedah Analisis Sempadan Stokastik(ASS) bagitahun 2003 dan 2004 yang terdiri daripada 65 buah dana daripada 16 buah syarikat pengurusan dana saham amanah di Malaysia. Dana yang dikaji dibahagikan kepada tiga jenis, iaitu pertumbuhan, pendapatan dan Islam/Syariah menggunakan spesifikasi Battese dan Coelli (1992). Analisis data dan keputusan kajian menggunakan program Frontier Versi 4.1 (Coelli, 1996). Kecekapan merupakan pengukuran penting yang boleh digunakan untuk menilai perkembangan dan pertumbuhan ekonomi sesebuah negara.
\end{abstract}

Kata kunci: Kecekapan; analisis sempadan stokastik (ASS); Spesifikasi Battese dan Coelli (1992).

\begin{abstract}
ABSTARCT
Purpose - This paper measures the relative efficiency of unit trust in Malaysia for the year 2003 and 2004, consisting of 65 funds from 16 unit trust management company which are categorised into three types; growth fund, income fund, and Islamic fund. The importance of this study can help the investor/trustee to choose the most efficient fund.
\end{abstract}

Design/Methodology/Approach - The study employed the production model by Battese and Coelli (1992). Frontier software Version 4.1 was used to analyse 
the efficiency score of unit trust funds and to estimate the parameters of stochastic production using maximum likelihood method.

Findings - Score efficiency analysis is important to measure the level of technical efficiency in the unit trust industry and other industries. The growth fund showed increasing efficiency score when tested funds were categorised depending on the type or the investment objectives. The mean of efficiency score for the growth fund in 2003 is $95 \%$ and $99 \%$ in 2004. Entirely, the income fund in 2003 was more efficient than 2004 with 100\% mean efficiency in 2003 and 93\% in 2004. However, both funds were still considered as excellent and efficient. Meanwhile, the Islamic fund had low efficiency scores with 73\% in 2003 and 84\% in 2004.

Originality/Value - The paper investigated extensively the relative efficiency and highlights these to investors, policy makers of unit trust, the unit trust industry and other industries.

Keywords - Efficiency; stochastic frontier analysis (SFA); Specification of Battese and Coelli 1992).

\section{Pengenalan}

Industri saham amanah memainkan peranan yang penting dalam pertumbuhan ekonomi sesebuah negara. Saham amanah wujud sejak kurun ke-18 bermula di kota London tetapi hanya terkenal di United Kingdom, Amerika Syarikat dan Australia pada tahun 70-an. Perintis sebenar dalam industri ini ialah The Foreign and Colonial Government Trust yang ditubuhkan di London pada tahun 1868 (Siti, 1995). Pada tahun 1890-an banyak dana saham amanah "closed-end" dengan bilangan unit yang boleh dikeluarkan terhad ditubuhkan oleh syarikat-syarikat besar di Scotland. Ini menyebabkan idea mengumpulkan modal secara tabungan untuk faedah semua pihak mula diterima oleh ahli korporat dan masyarakat.

Industri saham amanah mula dibawa masuk ke Malaysia pada akhir tahun 1950-an oleh sekumpulan pelabur berbangsa Inggeris yang menetap di Singapura. Pada tahun 1959 mereka telah melantik firma akauntan Cooper Brothers \& Company sebagai setiausaha mereka bagi memperbadankan syarikat saham amanah yang pertama yang dinamakan Malayan Unit Trust Limited. Hanya terdapat tiga saham amanah dalam pasaran sebelum tahun 1970-an, iaitu Malayan Unit Trust, Asia Unit Trust dan Amanah Saham MARA. Sehingga 31 Disember 1999, terdapat 95 dana diurus oleh 32 buah syarikat membabitkan 47.3 bilion unit bernilai lebih kurang RM33.7 bilion. Selepas itu, bilangan dan jenis Skim Saham Amanah meningkat dan membangun dari setahun ke setahun dan terus berkembang pesat dalam menongkah arus globalisasi yang mencabar. 


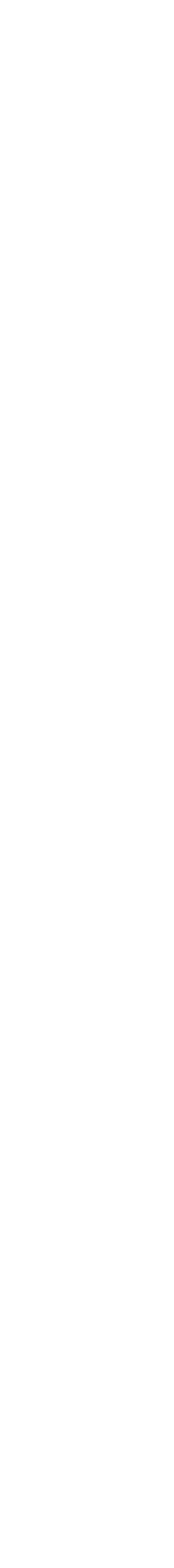

Krisis ekonomi yang melanda pada tahun 1997 telah menyebabkan masyarakat berhati-hati untuk menceburi bidang pelaburan. Setelah menghadapi kesuraman krisis tersebut, industri saham amanah dilihat semakin mendapat perhatian daripada orang ramai berbanding dengan tahun-tahun awal penubuhannya. Selain faktor risiko yang rendah, faktor pasaran saham yang memberangsangkan menyebabkan lebih banyak pelabur melabur dan industri ini terus mengorak langkah ke hadapan untuk bersaing dengan saham amanah global seiring dengan pertumbuhan ekonomi negara yang membangun dengan pesat.

Kecekapan menjadi nadi kecemerlangan kerana kecekapan menjadi pengukur keuntungan. Apabila syarikat saham amanah cekap, ini bermakna mereka dapat mengendalikan sumber modal dengan mengurus perbelanjaan secara berkesan pada tahap yang optimum. Analisis kecekapan adalah penting bagi mengukur tahap kecekapan teknikal dalam industri saham amanah dan industri lain. Pendekatan ini boleh menjadi sempadan berketentuan dengan semua sisihan daripada sempadan yang dianggap sebagai hasil kepada ketidakcekapan atau sempadan akan dipertimbangkan untuk penambahbaikan.

\section{Spesifikasi Model Sempadan Stokastik}

Fungsi pengeluaran sempadan stokastik telah diperkenalkan oleh Aigner, Lovell \& Schmidt (1977) dan Meeusen \& Van den Broeck (1977). Spesifikasi model ini terdiri daripada fungsi pengeluaran yang biasa dan komponen sebutan ralat (error term). Komponen ralat ini merangkumi kesan rawak (random effects) dan ketidakcekapan teknikal (technical inefficiency). Fungsi pengeluaran sempadan merupakan output maksimum yang dapat dicapai oleh sesebuah firma dengan input yang tertentu. Ianya semakin memainkan peranan yang penting dalam jangkaan dan anggaran untuk sesebuah firma dalam sesuatu industri. Banyak bentuk fungsi yang digunakan dalam mengkaji hubungan antara input dengan output. Bentuk fungsi paling popular yang digunakan ialah fungsi pengeluaran Battese dan Coelli (1992). Secara keseluruhan objektif kajian adalah untuk menentukan prestasi kecekapan teknikal berasaskan data-data yang diperoleh daripada Suruhanjaya Sekuriti.

Kajian ini mempertimbangkan multiinput dan satu output. Pendekatan ini dapat meramalkan output daripada input. Model tersebut diungkapkan seperti berikut:

$$
\ln Y_{i t}=\beta_{0}+\beta_{1} \ln x_{1 i t}+\beta_{2} \ln x_{2 i t}+\beta_{3} \ln x_{3 i t}+v_{i t}-u_{i t}
$$

IJMS 17 (1), 189-202 (2010) 
dengan

$Y_{i t}=$ pulangan bagi setiap dana ke-i pada masa $t$,

$\beta=$ ialah vektor bagi parameter yang tidak dikenali.

$x_{1 i t}=$ nisbah perbelanjaan pengurusan (MER) bagi setiap dana ke- $i$ pada masa $t$,

$x_{2 i t}=$ caj pembelian bagi setiap dana ke-i pada masa $t$,

$x_{3 i t}=$ yuran tahunan bagi setiap dana ke-i pada masa $t$,

$t=$ masa

$v_{i t}=$ pemboleh ubah rawak yang diandaikan tertabur secara merdeka dan secaman (iid) dan bertaburan normal dengan $v_{i t} \sim\left(0, \sigma_{v}^{2}\right)$,

$u_{i t}=$ pemboleh ubah rawak tak negatif yang diandaikan untuk mengira ketidakcekapan teknikal dalam pengeluaran dan dianggap menjadi sebagai $\left\{u_{i} \sim\right.$ iid $\left.\left[N\left(0, \sigma_{v}^{2}\right)\right]\right\}$.

Menurut Kumbhakar (1990), Battese dan Coelli (1992) telah membuat penambahbaikan terhadap model yang dapat digunakan bagi mengukur kelakuan masa bagi ketidakcekapan:

$m_{i t}=m_{i}\{\exp [-g(t-T]\}$

$$
\begin{aligned}
& i=1,2, \ldots, N \\
& t=1,2, \ldots, T
\end{aligned}
$$

dengan

- $\quad m_{i} » \mathrm{~N}^{+}\left(m, s^{2}\right)$ dan g ialah parameter yang akan dianggar.

- Ketidacekapan dalam selang masa sebelum $T$ bergantung kepada parameter $\gamma$.

- $m_{i t}=m_{i}$ penanda aras atau rujukan.

- Ketidakcekapan dalam selang masa sebelum $T$ ialah hasil tambah ketidakcekapan setiap akhir tahun.

- $\quad \exp [g(T-t)]$

- jika $\gamma$ adalah positif, ketidakcekapan menyusut mengikut masa

- jika $\gamma$ adalah tidak positif, ketidakcekapan meningkat mengikut masa

192 IJMS 17 (1), 189-202 (2010) 
Berikutan dengan itu, Battese dan Coelli (1992) telah mengusulkan fungsi pengeluaran sempadan stokastik bagi panel data yang mana mengandungi kesan firma yang diandaikan bertaburan sebagai pemboleh ubah rawak terpangkas normal dan juga membenarkan model berubah mengikut tempoh masa. Kelebihan yang nyata yang terdapat pada Analisis Sempadan Stokastik (ASS) ialah penggunaan data panel. Data panel memberikan bukti yang lebih kukuh terhadap prestasi kerana dapat mengenalpasti prestasi setiap pengeluar melalui suatu siri tempoh masa. Ulasan ke atas kesusasteraan kajian-kajian ini adalah seperti Forsund, Lovell dan Schmidt (1980), Schmidt (1986), Bauer (1990) dan Greene (1993).

Kaedah penganggaran kebolehjadian maksimum (ML) digunakan untuk menganggar fungsi pengeluaran sempadan stokastik yang terdiri daripada dua komponen ralat iaitu $\left(\boldsymbol{v}_{i}-\boldsymbol{u}_{i}\right)$. Kaedah ini memberi kesan yang lebih memuaskan kerana lebih cekap berbanding dengan kaedah Kuasa Dua Terkecil (OLS) (Richmond, 1974).

Untuk mengira ketidakcekapan teknikal dan pengeluaran, Aigner et al. (1977) menerbitkan fungsi kebolehjadian dalam bentuk parameter dua varians, $\sigma_{v}^{2}$ dan $\sigma_{u}^{2}$ dengan $\sigma^{2}=\sigma_{v}^{2}+\sigma_{u}^{2}$ dan $\lambda=\sigma_{u} / \sigma_{v}$. Battese dan Corra (1977) memparameterkan semula fungsi kebolehjadian dengan menggantikan $\sigma_{v}^{2}$ dan $\sigma_{u}^{2}$ dengan $\sigma^{2}=\sigma_{v}^{2}+\sigma_{u}^{2}$ dan $\gamma=\sigma_{u}^{2} / \sigma^{2}$. Parameter $\gamma$, mestilah berada dalam julat antara 0 dan 1 . Parameter bagi fungsi pengeluaran stokastik tersebut akan dianggarkan dengan menggunakan kaedah penganggaran ML dan pengiraan dilakukan menggunakan perisian Frontier Versi 4.1c (Coelli, 1996).

Dalam kajian ini, parameter $\gamma$ adalah penting kerana memudahkan penganalisisan tahap kecekapan dana dan sekali gus bertujuan untuk menguji sama ada ketiga-tiga dana yang dikaji cekap ataupun tidak. Statistik ujian $t$ dan taburan $t$ digunakan. Aras keertian yang digunakan ialah $\alpha=$ 0.05. Hipotesis kajian adalah seperti berikut:

$H_{0}: \gamma=0$ (tiada kecekapan teknikal dalam dana yang dikaji).

$H_{1}: \gamma>0$ (wujud kecekapan teknikal dalam dana yang dikaji).

\section{Keputusan Berangka}

Kajian ini terbahagi kepada tiga jenis dana iaitu dana pertumbuhan, dana pendapatan dan dana Islam/Syariah bagi tahun 2003 dan 2004 yang terdiri daripada 65 buah dana daripada 16 buah syarikat pengurusan dana saham amanah di Malaysia. Tahun 2003 dan 2004 dipilih kerana tempoh masa industri saham amanah berada pada fasa yang agak stabil setelah

IJMS 17 (1), 189-202 (2010) 
melalui beberapa proses pemulihan ekonomi. Ini membolehkan pengkaji memerhatikan perubahan kadar prestasi antara dana yang berada dalam industri ini. Menurut Norton (1999) untuk melihat kecekapan sesebuah dana, dana sepatutnya dibandingkan dengan dana daripada jenis yang sama. Ini adalah kerana dana yang berlainan jenis mempunyai jangkaan pulangan dan risiko yang berbeza-beza.

Keputusan kajian ditafsir dengan melihat kepada skor kecekapan. Berdasarkan hasil kajian yang diperoleh, didapati bahawa secara keseluruhannya prestasi kecekapan begitu menggalakkan bagi dana pertumbuhan dan pendapatan manakala terdapat sebilangan dana Islam/ Syariah yang mempunyai skor kecekapan yang rendah. (Sila rujuk Jadual 1, Jadual 3 dan Jadual 5).

Skor kecekapan dana saham amanah berada antara nilai 0 hingga 1. Skor kecekapan bernilai 1 menggambarkan dana ialah 100\% cekap. Sebaliknya, nilai yang semakin kurang daripada 1 menggambarkan ketidakcekapan dana. Dengan meletakkan pangkat ke atas setiap dana, maka mudah untuk mengecamkan susunan dana yang paling cekap kepada yang kurang cekap.

\section{Analisis Kecekapan Relatif Dana Pertumbuhan}

Merujuk kepada Jadual 1, skor kecekapan menunjukkan prestasi dana saham amanah amat memberangsangkan. Purata skor kecekapan bagi dana pertumbuhan pada tahun 2003 ialah 95\% dan pada tahun 2004 ialah 99\%. Bagaimanapun, pertumbuhan pada tahun 2004 lebih cekap dari tahun 2003. Skor kecekapan Dana Apex Malaysia Growth Trust, Dana Mayban Balanced Trust, Dana OSK-UOB Equity Trust, Dana Phillip Master Equity Growth, Dana Phillip Master First Ethical, Dana RHB Capital, Dana RHB Malaysia Recovery dan Dana SBB Double Growth mempunyai skor kecekapan yang sama dan mencatatkan dana yang paling cekap iaitu sebanyak $96 \%$ pada tahun 2003 dan 99\% pada tahun 2004 .

Seterusnya, pada tahun 2003, Dana HLG Growth dan KMB Dana Pertumbuhan menunjukkan skor kecekapan yang terendah iaitu $94 \%$. Namun begitu, skor tersebut masih dianggap cekap. Ini turut disokong oleh hasil kajian Sena (2003) yang menyatakan bahawa purata kecekapan melebihi $90 \%$ adalah dianggap cekap dan cemerlang.

Purata skor kecekapan pada tahun 2004 menghampiri nilai 1. Ini membayangkan prestasi dana pertumbuhan konsisten dan stabil serta memperlihatkan kejayaan pihak pengurusan dalam mempertingkat prestasi kecekapan mereka. Ini mungkin dipengaruhi oleh keyakinan orang ramai terhadap syarikat yang dikatakan telah bertapak kukuh dalam industri saham amanah. Ini disebabkan para pelabur kini semakin bijak dalam merancang dan memilih pelaburan mereka.

194 IJMS 17 (1), 189-202 (2010) 


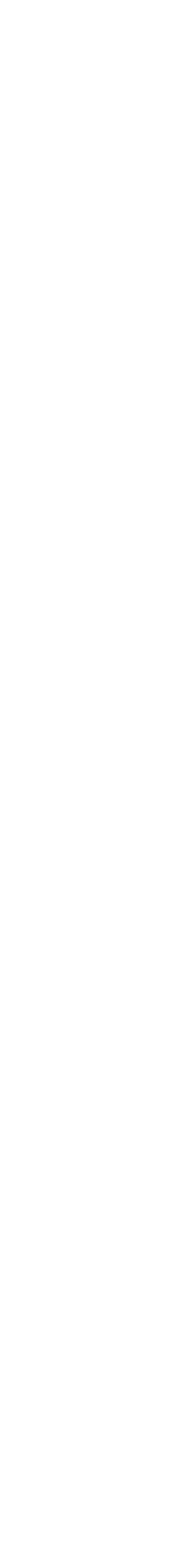

Kejayaan untuk membayar dividen dan mengumumkan pengagihan pendapatan kepada para pelabur merupakan antara penyumbang kecekapan terhadap dana pertumbuhan. Hal ini menyebabkan para pelabur terus berasa yakin untuk terus melabur dan bersikap rasional dalam pelaburan yang dijalankan. Pelaburan saham amanah hanya tertumpu di dalam negara sahaja dan kurang menerima sebarang kesan situasi ekonomi sekarang. Tidak hairanlah terdapat peningkatan keuntungan bagi dana pertumbuhan. Selain itu, melabur dalam industri barangan pengguna merupakan pelaburan terbaik untuk mendapat keuntungan memandangkan jualan barangan pengguna biasanya tidak terjejas walaupun kemelesetan ekonomi melanda.

Jadual 1

Skor Kecekapan Relatifantara Dana Saham Amanah Jenis Dana Pertumbuhan bagi Tahun Berakhir 2003 dan 2004

\begin{tabular}{|c|c|c|c|c|c|c|}
\hline \multirow[t]{2}{*}{ Bil. Dana-dana } & \multicolumn{2}{|c|}{ Skor Kecekapan } & \multicolumn{2}{|c|}{ Peratus } & \multicolumn{2}{|c|}{ Pangkat } \\
\hline & 2003 & 2004 & 2003 & 2004 & 2003 & 2004 \\
\hline 1. Apex Malaysia Growth Trust & 0.96 & 0.99 & 96 & 99 & 1 & 1 \\
\hline 2. ASM Balanced Fund & 0.95 & 0.98 & 95 & 98 & 2 & 2 \\
\hline 3. HLG Growth Fund & 0.94 & 0.98 & 94 & 98 & 3 & 2 \\
\hline 4. KMB Dana Pertumbuhan & 0.94 & 0.98 & 94 & 98 & 3 & 2 \\
\hline 5. MAAKL Growth Fund & 0.95 & 0.99 & 95 & 99 & 2 & 1 \\
\hline 6. Mayban Balanced Trust & 0.96 & 0.99 & 96 & 99 & 1 & 1 \\
\hline 7. OSK-UOB Equity Trust & 0.96 & 0.99 & 96 & 99 & 1 & 1 \\
\hline 8. Pacific Pearl Fund & 0.95 & 0.99 & 95 & 99 & 2 & 1 \\
\hline 9. Phillip Master Equity Growth & 0.96 & 0.99 & 96 & 99 & 1 & 1 \\
\hline 10. Phillip Master First Ethical Fund & 0.96 & 0.99 & 96 & 99 & 1 & 1 \\
\hline 11. PRU Balanced Fund & 0.95 & 0.99 & 95 & 99 & 2 & 1 \\
\hline 12. PRU Growth Fund & 0.95 & 0.99 & 95 & 99 & 2 & 1 \\
\hline 13. Public Growth Fund & 0.95 & 0.99 & 95 & 99 & 2 & 1 \\
\hline 14. RHB Balanced Fund & 0.95 & 0.98 & 95 & 98 & 2 & 2 \\
\hline 15. RHB Capital Fund & 0.96 & 0.99 & 96 & 99 & 1 & 1 \\
\hline 16. RHB Malaysia Recovery Fund & 0.96 & 0.99 & 96 & 99 & 1 & 1 \\
\hline 17. RHB Technology Fund & 0.95 & 0.99 & 95 & 99 & 2 & 1 \\
\hline 18. TMT Focus Fund & 0.95 & 0.98 & 95 & 98 & 2 & 2 \\
\hline 19. SBB Double Growth Fund & 0.96 & 0.99 & 96 & 99 & 1 & 1 \\
\hline 20. SBB HGF Sequel Fund & 0.95 & 0.99 & 95 & 99 & 2 & 1 \\
\hline 21. SBB Premium Capital Fund & 0.95 & 0.98 & 95 & 98 & 2 & 2 \\
\hline 22. SBB Savings Fund & 0.95 & 0.98 & 95 & 98 & 2 & 2 \\
\hline Purata Skor Kecekapan & 0.95 & 0.99 & 95 & 99 & & \\
\hline
\end{tabular}

Sumber. Paparan Output Model Battese dan Coelli (1992).

Berdasarkan kepada penggunaan Model Battese dan Coelli (1992), secara relatifnya keputusan kajian menunjukkan prestasi yang meningkat antara

IJMS 17 (1), 189-202 (2010) 
dua puluh dua buah dana pertumbuhan pada tahun 2003 hingga 2004. Didapati parameter gamma, $\gamma$ bagi anggaran kebolehjadian maksimum ialah 0.1218 . Keputusan yang diperoleh daripada pengujian hipotesis terhadap dana didapati statistik $t$ yang dikira ialah 2.2943 dan lebih besar daripada nilai $t$ kritikal 1.7341, $\left(t_{\text {kiran }}=2.2943>t_{0.05,18}=1.7341\right)$. Dengan itu hipotesis nol ditolak pada aras keertian 0.05 . Ini bermakna dana pertumbuhan berada pada tahap yang cekap.

Selain itu, keputusan penganggaran (ML) mendapati bahawa keanjalan pengeluaran pulangan bagi jumlah caj pembelian adalah paling tinggi iaitu 1.26. Ini bermakna peningkatan $1 \%$ dalam input caj pembelian akan meningkatkan sebanyak 1.26\% dalam pulangan dana. Bagi input MER pula, keanjalan pengeluaran pulangan adalah 0.86 . Ini bermaksud, peningkatan $1 \%$ dalam input MER menyebabkan peningkatan berlaku sebanyak $0.86 \%$ dalam pulangan dana.

Jadual 2

Keputusan Penganggaran ML Analisis Kecekapan Saham Amanah bagi Dana Pertumbuhan

\begin{tabular}{lcc}
\hline Parameter & Pekali & Nilai $t$ \\
\hline Pintasan & $\beta_{0}=-0.1990$ & -0.3055 \\
MER & $\beta_{1}=0.8557$ & $1.7457^{*}$ \\
Caj pembelian & $\beta_{2}=1.2562$ & $1.8673^{*}$ \\
Yuran tahunan & $\beta_{3}=0.9489$ & 0.9616 \\
Gamma & $\gamma=0.1218$ & $2.2943^{*}$ \\
\hline
\end{tabular}

* signifikan pada aras keertian 0.05 .

\section{Analisis Kecekapan Relatif Dana Pendapatan}

Skor kecekapan bagi dana pendapatan pada tahun 2003 adalah 100\% cekap kecuali Dana AUTB Bond iaitu 99\%. Secara relatifnya, dana pendapatan pada tahun 2003 lebih cekap dari tahun 2004 dengan purata skor kecekapan $100 \%$ (2003) dan 93\% (2004). Namun begitu, secara keseluruhannya jenis - dana pendapatan pada tahun 2003 dan 2004 berada dalam tahap yang cekap dan cemerlang (Sena, 2003).

Melalui hasil output, skor kecekapan terendah jenis dana pendapatan pada tahun 2004 ialah Dana AUTB Bond dengan skor kecekapan 87\%. Manakala terdapat sembilan dana yang mempunyai skor kecekapan yang tertinggi iaitu sebanyak 94\% yang terdiri daraipada Dana Affin Equity, Dana ASM Ketiga, Dana ASM Keenam, Dana ASM Premier, Dana AS Nasional, Dana AS Nasional 2, Dana OSK-UOB Kidsave Trust, Dana Pacific Millennium dan Dana Public Saving. Skor kecekapan bagi dana-dana lain pula masih lagi berada pada kadar yang membanggakan. 


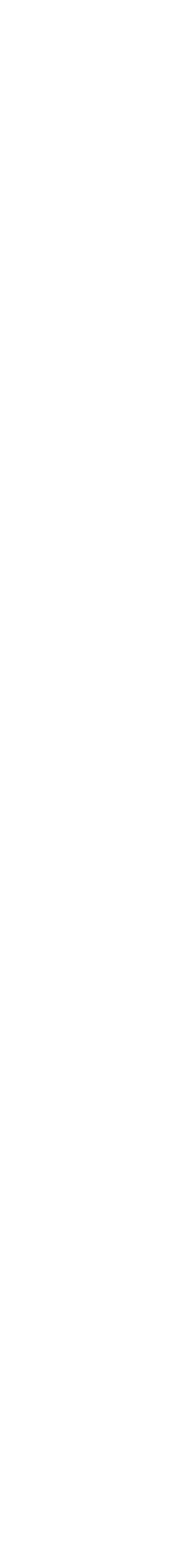

Didapati bahawa skor kecekapan mempunyai penurunan dari tahun 2003 ke 2004. Salah satu faktor yang dikenal pasti kemerosotan kecekapan ini disebabkan oleh saham amanah mempunyai hubungan dengan pasaran saham negara. Walaupun dari segi nama ianya dipanggil saham amanah, tetapi bentuk pelaburan yang dibuat ialah melabur dalam Bursa Saham Kuala Lumpur (BSKL) dan bukannya melabur dalam projek-projek kerajaan seperti yang disangka oleh sesetengah pihak. Ini bermakna prestasi saham amanah bergantung kepada kedudukan pasaran saham negara.

Jadual 3

Skor Kecekapan Relatif antara Dana Saham Amanah Jenis Dana Pendapatan bagi Tahun Berakhir 2003 dan 2004

\begin{tabular}{|c|c|c|c|c|c|c|c|}
\hline \multirow[t]{2}{*}{ Bil. } & \multirow[t]{2}{*}{ Dana-dana } & \multicolumn{2}{|c|}{ Skor Kecekapan } & \multicolumn{2}{|c|}{ Peratus } & \multicolumn{2}{|c|}{ Pangkat } \\
\hline & & 2003 & 2004 & 2003 & 2004 & 2003 & 2004 \\
\hline 1. & Affin Equity Fund & 1.00 & 0.94 & 100 & 94 & 1 & 1 \\
\hline 2. & AS Bumiputera & 1.00 & 0.93 & 100 & 93 & 1 & 2 \\
\hline 3. & AS Didik & 1.00 & 0.93 & 100 & 93 & 1 & 2 \\
\hline 4. & AS Malaysia & 1.00 & 0.93 & 100 & 93 & 1 & 2 \\
\hline 5. & ASM First Public Fund & 1.00 & 0.93 & 100 & 93 & 1 & 2 \\
\hline 6. & ASM Ketiga & 1.00 & 0.94 & 100 & 94 & 1 & 1 \\
\hline 7. & ASM Kelima & 1.00 & 0.92 & 100 & 92 & 1 & 3 \\
\hline 8. & ASM Keenam & 1.00 & 0.94 & 100 & 94 & 1 & 1 \\
\hline 9. & ASM Ketujuh & 1.00 & 0.92 & 100 & 92 & 1 & 3 \\
\hline 10. & ASM Kesepuluh & 1.00 & 0.93 & 100 & 93 & 1 & 2 \\
\hline 11. & ASM Kesebelas & 1.00 & 0.93 & 100 & 93 & 1 & 2 \\
\hline 12. & ASM Premier Fund & 1.00 & 0.94 & 100 & 94 & 1 & 1 \\
\hline 13. & AS Nasional & 1.00 & 0.94 & 100 & 94 & 1 & 1 \\
\hline 14. & AS Nasional 2 & 1.00 & 0.94 & 100 & 94 & 1 & 1 \\
\hline 15. & AS Nasional 3 & 1.00 & 0.93 & 100 & 93 & 1 & 2 \\
\hline 16. & ASW 2020 & 1.00 & 0.93 & 100 & 93 & 1 & 2 \\
\hline 17. & AUTB Bond Fund & 0.99 & 0.87 & 99 & 87 & 2 & 5 \\
\hline 18. & Mayban Ethical Trust Fund & 1.00 & 0.91 & 100 & 91 & 1 & 4 \\
\hline 19. & Mayban Income Trust Fund & 1.00 & 0.93 & 100 & 93 & 1 & 2 \\
\hline 20. & Mayban Unit Trust Fund & 1.00 & 0.93 & 100 & 93 & 1 & 2 \\
\hline 21. & OSK-UOB Kidsave Trust & 1.00 & 0.94 & 100 & 94 & 1 & 1 \\
\hline 22. & Pacific Millennium Fund & 1.00 & 0.94 & 100 & 94 & 1 & 1 \\
\hline 23. & PB Fixed Income Fund & 1.00 & 0.93 & 100 & 93 & 1 & 2 \\
\hline 24. & Phillip Master Money Market & 1.00 & 0.93 & 100 & 93 & 1 & 2 \\
\hline 25. & Public Saving Fund & 1.00 & 0.94 & 100 & 94 & 1 & 1 \\
\hline 26 & RHB Dynamic Fund & 1.00 & 0.93 & 100 & 93 & 1 & 2 \\
\hline Pura & ata Skor Kecekapan & 1.00 & 0.93 & 100 & 93 & & \\
\hline
\end{tabular}

Sumber. Paparan Output Model Battese dan Coelli (1992).

IJMS 17 (1), 189-202 (2010) 
Dalam menganalisis penganggaran skor kecekapan bagi dua puluh enam buah dana pendapatan, pendekatan yang sama digunakan seperti hasil kajian pada bahagian sebelum ini. Parameter gamma, $\gamma$ bagi anggaran kebolehjadian maksimum bersamaan 0.1726. Berdasarkan keputusan pengujian hipotesis didapati bahawa $\left(t_{\text {kiraan }}=1.7264>t_{5 \%, 22}=1.7171\right)$. Dengan itu, hipotesis nol ditolak pada aras keertian 0.05. Oleh itu, dapat disimpulkan bahawa dana pendapatan berada dalam keadaan yang cekap.

Merujuk kepada Jadual 4, didapati bahawa keanjalan pengeluaran pulangan - bagi jumlah MER adalah paling tinggi iaitu 0.50. Ini bermakna peningkatan $1 \%$ dalam input MER akan meningkatkan sebanyak $0.50 \%$ dalam pulangan dana. Manakala bagi input caj pembelian, keanjalan pengeluaran pulangan adalah 0.21 . Ini bermaksud, peningkatan $1 \%$ dalam input caj pembelian akan menyebabkan hanya $0.21 \%$ peningkatan dalam pulangan dana.

Jadual 4

- Keputusan Penganggaran ML Analisis Kecekapan Saham Amanah bagi Dana Pendapatan

\begin{tabular}{lcc}
\hline Parameter & Pekali & Nilai $t$ \\
\hline Pintasan & $\beta_{0}=0.6883$ & $4.0963^{*}$ \\
MER & $\beta_{1}=0.4962$ & $1.7964^{*}$ \\
Caj pembelian & $\beta_{2}=0.2114$ & $2.7486^{*}$ \\
Yuran tahunan & $\beta_{3}=0.5984$ & -1.1176 \\
Gamma & $\gamma=0.1726$ & $1.7264^{*}$ \\
\hline
\end{tabular}

* signifikan pada aras keertian 0.05 .

\section{Analisis Kecekapan Relatif Dana Islam/Syariah}

Merujuk kepada Jadual 5, didapati bahawa dua tahun berturut-turut Dana Al-Aiman menunjukkan skor kecekapan yang paling rendah dan dianggap tidak cekap iaitu sebanyak 34\% pada tahun 2003 dan sebanyak 57\% pada tahun 2004. Seterusnya PRU Dana Al-Ilham dan Dana Public Ittikal mencatatkan skor kecekapan yang tertinggi bagi dua tahun berturut-turut iaitu sebanyak 86\% (2003) dan 93\% (2004). Manakala terdapat lima dana yang menunjukkan prestasi yang cemerlang dan menjadi panduan kepada dana-dana lain pada tahun 2004 iaitu ASM Dana Mutiara, Mayban Dana Yakin, OSK-UOB Dana Islam, Pacific Dana Aman dan PRU Dana Al-Islah dengan skor kecekapan sebanyak 92\%, 91\%, 92\%, 90\% dan 90\%. Purata skor kecekapan bagi dana Islam/Syariah pada tahun 2003 ialah $73 \%$ dan pada tahun 2004 ialah 84\%. Ini menunjukkan skor kecekapan yang kurang memuaskan secara relatifnya bagi kedua-dua tahun.

198 IJMS 17 (1), 189-202 (2010) 
Ketidakcekapan ini disebabkan oleh saham amanah mempunyai cara pelaburan yang berbeza. Bagi dana yang berteraskan Syariah, sekiranya Indeks Komposit BSKL meningkat akibat sokongan daripada kaunterkaunter yang bukan berteraskan Syariah, tidak bermakna saham amanah Syariah akan turut naik. Ini kerana saham amanah yang berteraskan Syariah tidak boleh melanggan kaunter tersebut, lantas tidak memberi kesan terhadap kedudukan portfolio pelaburannya.

Memandangkan bentuk pelaburan yang sebegini rupa, maka pulangan pelaburan adalah dalam bentuk keuntungan daripada pembelian saham. Sekiranya saham amanah yang dibeli tidak dapat dijual kerana harganya jatuh, maka tabung tidak akan memperoleh keuntungan. Tanpa keuntungan sudah tentu menyukarkan pengurus dana untuk membuat pengagihan pendapatan kepada para pelabur. Sebagai langkah mempertingkat tahap kecekapan, pelaburan yang dibuat oleh saham amanah yang berteraskan Syariah terpaksa dibuat secara berhati-hati kerana status pelaburan yang dibenarkan mengikut ketetapan Syariah berubah-ubah pada bila-bila masa berdasarkan aktiviti perniagaan yang dibuat oleh syarikat tersebut.

Jadual 5

Skor Kecekapan Relatif antara Dana Saham Amanah Jenis Dana Islam/Syariah bagi Tahun Berakhir 2003 dan 2004

\begin{tabular}{lllllrrr}
\hline Bil. Dana-dana & \multicolumn{1}{c}{ Skor Kecekapan } & \multicolumn{2}{c}{ Peratus } & \multicolumn{2}{c}{ Pangkat } \\
& & 2003 & 2004 & 2003 & 2004 & 2003 & 2004 \\
\hline 1. & Affin Islamic Fund & 0.72 & 0.85 & 72 & 85 & 10 & 8 \\
2. Apex Dana Al-Faiz & 0.65 & 0.80 & 65 & 80 & 12 & 10 \\
3. ASM Dana Mutiara & 0.84 & 0.92 & 84 & 92 & 2 & 2 \\
4. & AUTB Dana Bakti & 0.66 & 0.81 & 66 & 81 & 11 & 9 \\
5. Dana Al-Aiman & 0.34 & 0.57 & 34 & 57 & 15 & 13 \\
6. Dana Bestari & 0.76 & 0.87 & 76 & 87 & 7 & 6 \\
7. & HLG Dana Makmur & 0.47 & 0.68 & 47 & 68 & 14 & 12 \\
8. MAAKL Syariah Indek & 0.74 & 0.86 & 74 & 86 & 8 & 7 \\
9. Mayban Dana Yakin & 0.83 & 0.91 & 83 & 91 & 3 & 3 \\
10. OSK-UOB Dana Islam & 0.84 & 0.92 & 84 & 92 & 2 & 2 \\
11. Pacific Dana Aman & 0.82 & 0.90 & 82 & 90 & 4 & 4 \\
12. PRU Dana Al-Ilham & 0.86 & 0.93 & 86 & 93 & 1 & 1 \\
13. PRU Dana Al-Islah & 0.81 & 0.90 & 81 & 90 & 5 & 4 \\
14. Public Ittikal Fund & 0.86 & 0.93 & 86 & 93 & 1 & 1 \\
15. RHB Mudharabah Fund & 0.60 & 0.77 & 60 & 77 & 13 & 11 \\
16. SBB Dana Al-Ihsan & 0.73 & 0.85 & 73 & 85 & 9 & 8 \\
17. SBB Dana Al-Ihsan 2 & 0.79 & 0.89 & 79 & 89 & 6 & 5 \\
\hline Purata Skor Kecekapan & 0.73 & 0.84 & 73 & 84 & & \\
\hline
\end{tabular}

Sumber. Paparan Output Model Battese dan Coelli (1992). 
Pendekatan yang sama digunakan dalam menganalisis tahap kecekapan ke atas tujuh belas buah dana Islam/Syariah. Parameter gamma, $\gamma$ daripada Jadual 6 bersamaan 0.6059. Berdasarkan keputusan ujian hipotesis ke atas dana Islam/Syariah didapati bahawa statistik $t$ yang dikira 1.0736 dan ianya lebih kecil daripada nilai $t$ kritikal 1.7709, $\left(t_{\text {kiraan }}=1.0736<t_{5 \%, 13}=1.7709\right)$. Dengan itu hipotesis nol gagal ditolak pada aras keertian 0.05. Ini mengukuhkan dakwaan bahawa dana Islam/Syariah barada pada tahap yang tidak cekap.

- Jadual 6

Keputusan Penganggaran ML Analisis Kecekapan Saham Amanah bagi Dana Islam/Syariah

\begin{tabular}{lcc}
\hline Parameter & Pekali & Nilai $t$ \\
\hline Pintasan & $\beta_{0}=1.7941$ & 1.3697 \\
MER & $\beta_{1}=0.8147$ & 1.0623 \\
Caj pembelian & $\beta_{2}=-1.2512$ & -0.8124 \\
Yuran tahunan & $\beta_{3}=1.0084$ & 0.2885 \\
Gamma & $\gamma=0.6059$ & 1.0736 \\
\hline
\end{tabular}

* signifikan pada aras keertian 0.05 .

\section{Kesimpulan}

Analisis kecekapan adalah penting bagi mengukur tahap kecekapan teknikal dalam industri saham amanah dan industri lain. Pendekatan Analisis Sempadan Stokastik (ASS) yang melibatkan penggunaan kaedah ekonometrik digunakan untuk menganalisis tahap kecekapan dana secara relatif. Model Battese dan Coelli (1992) digunakan untuk mendapatkan skor kecekapan setiap dana.

Apabila dana yang dikaji dikategorikan mengikut jenis atau objektif pelaburannya, didapati dana pertumbuhan secara relatif mencatatkan peningkatan kecekapan yang memberangsangkan iaitu meningkat sebanyak 95\% pada tahun 2003 kepada 99\% pada tahun 2004. Purata skor kecekapan ini dianggap cekap dan cemerlang (Sena, 2003). Ini sejajar dengan objektif dana jenis ini yang mengutamakan pulangan modal yang maksimum dalam jangka masa panjang. Manakala purata skor kecekapan dana pendapatan pada tahun 2003 100\% cekap berbanding purata skor kecekapan sebanyak 93\% pada tahun 2004. Namun begitu, dana pendapatan bagi kedua-dua tahun masih berada dalam tahap yang cekap. Ini adalah kerana prestasi tabung bagi dana ini berupaya mencapai objektif pelaburannya dalam 
menjana pulangan jangka panjang yang kompetitif dan konsisten kepada para pelabur.

Bagi dana Islam/Syariah, tahap kecekapan didapati berada pada tahap yang kurang memuaskan, walaupun ianya mencatatkan peningkatan purata skor kecekapan sebanyak 73\% pada tahun 2003 kepada 84\% pada tahun 2004. Ini mungkin disebabkan oleh kekangan dalam pemilihan sekuriti yang lebih agresif supaya selaras dengan prinsip Syariah, yang mana dana ini tidak melabur dalam saham yang menyalahi hukum-hukum syarak. Contohnya pelaburan yang melibatkan urus niaga seperti premis perjudian, produk tembakau, minuman beralkohol dan pelaburan yang tidak halal. Keputusan sedemikian adalah sejajar dengan konsep pulangan yang tinggi bersertakan risiko yang tinggi. Semakin tinggi risiko, semakin tinggi hasil pulangan yang diperoleh.

Melalui pangkat kecekapan, diharap dapat membantu para pelabur memilih dana yang benar-benar cekap. Kepentingan aplikasi ini juga dapat menguji hipotesis ekonomi. Ianya bukan sahaja dapat mengawasi daya produktiviti dan kecekapan sesuatu industri dari semasa ke semasa, malahan dapat membandingkan prestasi antara jabatan ataupun cawangan firma. Dari semasa ke semasa, kecekapan operasi dapat ditingkatkan dan dapat membantu pengeluar memperbaik tahap kecekapan sesuatu industri bagi memaksimumkan jumlah pengeluaran atau perkhidmatan yang akan diberikan kepada pelanggan.

\section{Rujukan}

Aigner, D., Lovell, C.A.K., \& Schmidt, P. (1977). Formulation and estimation of stochastic frontier production function models. Journal of Econometrics, 6, 21-37.

Battese, G.E., \& Corra, G.S. (1977). Estimation of a production frontier model: With application to the pastoral zone of Eastern Australia. Australian Journal of Agricultural Economics, 21, 169-179.

Battese, G.E., \& Coelli, T.J. (1992). Frontier production function, technical efficiency and panel data: With application to paddy farmers in India. Journal of Productivity Analysis, 3, 153-169.

Bauer, P.W. (1990). Recent developments in the econometric estimation of frontiers. Journal of Econometrics, 46, 39-56.

Coelli, T.J. (1996). A computer program for stochastic frontier production and cost function estimation. frontier version 4.1: CEPA working paper 96/97, Department of Econometrics, University of New England.

IJMS 17 (1), 189-202 (2010) 
Forsund, F.R., Lovell, C.A.K., \& Schmidt, P. (1980). A survey of frontier production functions and of their relationship to efficiency measurement. Journal of Econometrics, 13, 5-25.

Greene, W.H. (1993). The econometric approach efficiency analysis. In Fried, H.O., Lovell, C.A.K. \&, S.S. Schmidt (Eds), The Measurements of Productive Efficiency, Oxford University Press, New York, 68-119.

Kumbhakar, S.C. (1990). Production frontier, panel data and time-varying technical inefficiency. Journal of Econometrics, 46, 201-211.

- Meeusen, W., \& Van den Broeck, J. (1977). Efficiency estimation from CobbDouglas production function with composed error. International Economic Review, 18, 435-444.

Norton, R.G. (1999). Investing for income: A bond mutual fund approach to highreturn, low-risk profit. New York: McGraw Hill.

Schmidt, P. (1986). Frontier production functions. Econometric Reviews, 4, 289-328.

Sena, V. (2003). The frontier approach to the measurement of productivity and technical efficiency. Economic Issues 8.

Siti Zaleha Feroze Din. (1995). Saham amanah ekuiti perancangan kewangan jangka panjang. Unitra Research Enterprise.

Richmond, J. (1974). Estimating the efficiency of production. International Economic Review, 15, 515-521.

202 IJMS 17 (1), 189-202 (2010) 